\title{
Edwards v. Arizona: The Burger Court Breathes New Life Into Miranda
}

In Edwards v. Arizona, ${ }^{1}$ the United States Supreme Court held that when an accused has invoked the right to counsel during custodial interrogation, courts may note infer a waiver of that right when the accused subsequently responds to police-initiated questioning. The Court further held that once the right to counsel is exercised, no subsequent interrogation of the accused will be permitted in the absence of counsel unless the accused himself initiates the conversation with the police.

Part I of this Note states the facts of the case and describes the Court's opinion. Part II examines the legal background of the invocation and waiver of Miranda rights. Part III first interprets Edwards as creatimg a per se rule, proscribing any interrogation of an accused who has invoked his right to counsel. Second, it considers why the Supreme Court saw fit to create such a rule. Third, it provides an analytical framework for courts attempting to apply this rule. Finally, this Note considers the impact $E d w a r d s$ will have on existing law.

\section{I}

\section{FACTS AND OPINION}

Robert Edwards was arrested at his home on charges of robbery, burglary, and inurder. He was taken to the local police station, and there given his Miranda warnings. Edwards indicated that he understood his rights and was willing to submit to interrogation. Though informed that he had been implicated by a co-conspirator, Edwards denied any involvement in the crime. He then expressed a desire to "make a deal" with the authorities. The officer told Edwards that he had no authority to inake such a deal, but gave him the number of the county attorney. Edwards did not pursue this contact, but stated, "I want an attorney before making a deal."2 Questioning immediately ceased and Edwards was taken to jail.

The following morning two detectives came to the jail to speak with him. When informed of their arrival, Edwards stated that he did not wish to speak to anyone. The guard told him that "he had to" talk

1. 101 S. Ct. 1880 (1981).

2. Id. at 1882 . 
and took him to the detectives. ${ }^{3}$ After his rights were read to him again, Edwards indicated that he was willing to talk, but first wanted to hear the tape of his alleged accomplice's statement. The detectives coinplied with his request, and after several minutes of listening to the tape, Edwards agreed to make a statement as long as it was not recorded. The detectives explamed that whether or not his statement was recorded, it could be used against him in court. Edwards replied, "I'll tell you anything you want to know, but I don't want it on tape." $4 \mathrm{He}$ then implicated himself in the crime.

Prior to trial, Edwards moved to suppress this confession on the ground that it had been taken in violation of Miranda. He argued that the officers should not have been allowed to reinterrogate him after he had invoked his right to counsel. The trial judge granted the motion to suppress, but reversed his ruling the next day on the basis of a supposedly controlling higher court opimion..$^{5}$ The confession was admitted into evidence, and Edwards was convicted. The Arizona Supreine Court affirmed. It held that Edwards waived both his right to remain silent and his right to counsel by voluntarily agreeing to speak with the officers. The court rejected the argument that Miranda created a per se rule prohibiting interrogation after a suspect mvokes his right to counsel. ${ }^{6}$

The Umited States Supreme Court unanimously reversed the conviction, determining that the use of Edwards' confession at trial had violated his rights under the fifth and fourteenth amendments. ${ }^{7}$ Writing for six members of the Court, Justice White concluded that the prosecution had failed to carry its heavy burden of proof for deinonstratimg a valid waiver of Miranda rights. Proving that the relinquishment of one's right to counsel was voluntary was not sufficient; to establish a valid waiver, the state must demonstrate that the waiver was knowingly and intelligently made. ${ }^{8}$

The Court further noted that Miranda inandates that all interrogation must cease upon the exercise of the right to counsel. ${ }^{9}$ To give substance to this view, the Court held that an accused who has mvoked his

3. Id.

4. Id.

5. The case relied upon was State v. Travis, 26 Ariz. App. 24, 545 P.2d 986 (1976). The trial court's initial decision to suppress was based on reasoning similar to the Supreme Court's ultimate lolding: "The detectives violated Miranda when they reapproached Edwards after his statement about an attorney." State v. Edwards, 122 Ariz. 206, 209-10, 594 P.2d 72, 75 (1979).

6. State v. Edwards, 122 Ariz, 206, 211, 594 P.2d 72, 77 (1979).

7. $101 \mathrm{~S}$. Ct. at 1882 . The Court noted that it was therefore not necessary to consider Edwards' claim that his sixth amendment right to counsel had been violated under the principles set out in Massiah v. United States, 377 U.S. 201 (1964). 101 S. Ct. at 1882 \& n.7.

8. $101 \mathrm{~S}$. Ct. at 1883.

9. Id. at 1885 . 
right to counsel is not subject to "further interrogation by the authorities until counsel has been made available to him, unless the accused himself intiates further communication, exchanges or conversations with the police." 10 According to the Court, "additional safeguards are necessary when the accused asks for counsel ...."11 These safeguards took the form of objective criteria-suspect-initiated dialogue or the presence of counsel-by which to evaluate the honoring of fifth amendinent rights. Thus, no valid waiver can be found when the suspect responds to further interrogation in the absence of counsel.

In a concurring opinion, Chief Justice Burger expressed the view that neither Miranda nor any constitutional standard requires a "special rule" for determining whether there has been a valid waiver of the right to be free from interrogation. That inquiry, he argued, is governed by the traditional standard established in Johnson $v$. Zerbst, by which a court inust look to the totality of the circumstances surrounding the case. ${ }^{12}$ Burger believed it would have been sufficient to hold that the state had failed to prove a voluntary waiver on these facts, since after Edwards stated that lie did not wish to talk with anyone, he was told that "he had to."13

Justice Powell, joined by Justice Rehnquist, also concurred with the result in Edwards, but questioned its approach. Powell felt that the empliasis on who initiates the conversation between the suspect and the officer was "undue and undefined." 14 According to Powell, the majority opinion could be read in two ways. The first created a per se rule which required a threshold inquiry into who initiated the conversation so as to determine the validity of the waiver. Powell disagreed with this displacement of established waiver doctrime. ${ }^{15}$ The second interpretation viewed the opinion as not departing from the established Zerbst standard. Preferring this interpretation, Powell saw no need to "constitutionalize" a single element of fact among all the facts and circumstances that are usually accounted for under a totality of the circumstances test. ${ }^{16}$

10. Id.

11. Id. at 1884 .

12. Id. at 1886 (Burger, C.J., concurring). In Johnson v. Zerbst, 304 U.S. 458 (1938), the Court held that a waiver is an "intentional relinquishment of a known right or privilege," the determination of which is based "in each case, upon the particular facts and circumstances surrounding that case, including the background, experience, and conduct of the accused." Id. at 464.

13. $101 \mathrm{~S}$. Ct. at 1886 (Burger, C.J., concurring).

14. Id. at 1888 (Powell, J., concurring).

15. Id. at 1887 .

16. Id. at 1888-89. Powell felt that such a step was unwarranted as there had been no showing that the traditional standard is ineffective. Id. at $1889 \mathrm{n} .2$. 
II

\section{LEGAL BACKGROUND}

Prior to the landmark case of Miranda $\nu$. Arizona,${ }^{17}$ confessions were held admissible if they were shown to be voluntary. ${ }^{18}$ Regardless of their possible reliability, coerced confessions were viewed as "revolting to the sense of justice," 19 undermining the entire procedure by which the state obtained a conviction. ${ }^{20}$ To satisfy due process inandates, a confession had to be the "product of an essentially free and unconstrained choice by the inaker," 21 requiring an inquiry into the "totality of the relevant circumstances" surrounding the confession. ${ }^{22}$

Miranda substantially changed the law with respect to confessions. Miranda established a presumption that custodial interrogation creates an inherently coercive setting. ${ }^{23}$ To overcome this coercion, the Court held that suspects need greater protection of their fifth ainendment rights than that provided by the voluntariness standard. ${ }^{24}$ To this end, the Court sought to employ procedural safeguards. ${ }^{25}$ Incriminating statements inade during custodial interrogation were now inadmissible unless the suspect liad been adequately apprised of his rights, imcluding the right to have counsel present during interrogation. ${ }^{26}$ The Court, inoreover, sought to fully honor the exercise of these rights, ${ }^{27}$ by char-

17. 384 U.S. 436 (1966).

18. See Culombe v. Connecticut, 367 U.S. 568 (1961); Brown v. Mississippi, 297 U.S. 278 (1930). See generally 8 J. WIGMORE, EvIDENCE \& 2266 (J. McNaughton rev. ed. 1961).

A "confession" has been defined as "any confession of guilt of any criminal offense or any self-imcriminating statement made or given orally or im writing." 18 U.S.C. $\$ 3501$ (e) (1969).

19. Brown v. Mississippi, 297 U.S. at 286.

20. Id. at 287. See, e.g., Rogers v. Richmond, 365 U.S. 534, 547-49 (1961). Much of the impetus for the line of decisions beginning with Brown came from the Wickersham Commission report on police abuses. 11 NATIONAL Commission ON LAW OBSERvanCE AND ENFORCEMENT, REPORT ON LAWLESSNESS IN LAW ENFORCEMENT (1931). See generally 3 J. Wigmore, EviDENCE $\$ 826$ (J. Chadbourn rev. ed. 1970); Kamisar, What is an "Involuntary" Confession?, 17 RutGERs L. Rev. 728 (1963); Developments in the Law-Confessions, 79 HARv. L. REv. 935 (1966) [heremafter cited as Developments].

21. Culombe v. Connecticut, 367 U.S. 568, 602 (1961).

22. Id. at 606; Haynes v. Washmgton, 373 U.S. 503, 513 (1963); Spano v. New York, 360 U.S. 315, 321-24 (1959). See generally 3 J. Wigmore, Evidence § 826 (J. Chadbourn rev. ed. 1970).

23. 384 U.S. at 467-79. The Court described the paradigm of this coercion as "incommunicado interrogation of individuals in a police-dominated atmosphere, resulting in self-incriminating statements without full warnings of constitutional rights." Id. at 445.

24. Id. at 457-67. The fifth amendment provides: "No person . . . shall be compelled in any criminal case to be a witness against himself . . ." U.S. ConST. amend. V. In Malloy v. Hogan, 378 U.S. 1 (1964), the Court extended the apphication of the self-incrimination clause to the states.

25. 384 U.S. at 478.

26. Id. at 467-76.

27. Id. at 467. The Court's directive to law enforcement agencies with regard to the honoring of a suspect's rights, once exercised, was unambiguous:

Once wamings have been given, the subsequent procedure is clear. If the individual indicates in any manner, at any time prior to or during questioning, that he wishes to 
acterizing any stateinent elicited after a suspect has invoked his privilege as the product of compulsion. ${ }^{28}$ The Court thus attempted to give enforcement agencies and courts clear, objective constitutional guidelines, ${ }^{29}$ and in so doing, moved towards replacing the "totality of the circumstances" approacl with a per se rule for fifth amendment violations.

The Miranda Court recognized that a suspect's rights could still be voluntarily waived during custody. ${ }^{30}$ As established in Johnson $v$. Zerbst, ${ }^{31}$ a valid waiver requires "an imtentional relinquishment or abandonment of a known right or privilege."32 However, when an individual does not have an attorney present, a heavy burden rests on the government to show a knowing and intelligent waiver. ${ }^{33}$ Moreover, a vahd waiver can never be presumed "simply from the silence of the accused after warnings are given or simply from the fact that a confession was in fact eventually obtained." $" 34$

In the years since Miranda, its teachings have had a steadily decreasing impact. Most noticeably, the transition from the Warren Court to the Burger Court evidenced a change in attitude concerning the very premises underlying that decision. ${ }^{35}$ Though Miranda has never been overruled, the pattern of post-Miranda opinions indicates the disfavor into which it has fallen. ${ }^{36}$ In the fifteen cases in which the Court has considered the scope of Miranda, fourteen have upheld the

remain silent, the interrogation must cease. At this point he has shown that he intends to exercise his Fifth Amendment privilege ... . If the individual states that he wants an attorney, the interrogation must cease until an attorney is present. At that time, the individual must have an opportunity to confer with the attorney and to have him present during any subsequent questioning. If the individual cannot obtain an attorney and he indicates that he wants one before speaking to police, they must respect his decision to remain silent.

Id. at $473-74$.
28. Id. at 474 .
29. Id. at $441-42$.
30. Id. at 475 .
31. 304 U.S. 458 (1938).
32. Id. at 464. See note 12 supra.
33. 384 U.S. at 475 .

34. Id. See Camley v. Cochran, 369 U.S. 506, 513-17 (1962); GIasser v. United States, 315 U.S. 60, 69-72 (1942).

35. See, e.g., Michigan v. Tucker, 417 U.S. 433 (1974). See generally Stone, The Miranda Doctrine in the Burger Court, 1977 Sup. CT. Rev. 99.

36. Various theories account for the fact that Miranda has not been overruled, including the controversy surrounding that opinion, the relatively minor impact it has had on the nuinber of confessions obtained, and the degrce to which it has become embedded in the public mind. See Schrock, Welsh \& Collins, Interrogational Rights: Reflections on Miranda v. Arizona, 52 S. CAL. L. REv. 1, 1-4 (1978); Stone, supra note 35, at 99, 169.

In Michigan v. Tucker, 417 U.S. 433 (1974), the Court seemed to lay the groundwork for overruling Miranda by noting that the requirenents set out in that opimion were not constitutional mandates, but were merely "prophylactic" guidelines for the protection of fifth amendment rights. 
admissibility of the challenged evidence. ${ }^{37}$ Only in an extreme case in which literally no evidence had been introduced to show a valid waiver was a statement held inadmissible. ${ }^{38}$ Moreover, recent cases suggest a return to the pre-Miranda voluntariness standard. ${ }^{39}$

Id. at 439. But because the interrogation in Tucker occurred before Miranda had been handed down, the case was in fact decided on narrower grounds. Id. at 447.

The recent case of Brewer v. Williams, 430 U.S. 387 (1977), sheds some additional light on the future of Miranda. In that case, Williams, had turned himself in to the Davenport, lowa police for the murder of a young girl. After consulting over the phone with his lawyer in Des Moines, Williams indicated that he would not speak with the authorities until he was returned to Des Moines and in the presence of his attorney. A local Davenport lawyer made certain that the detectives who would accompany Williams back to Des Moines understood this. Nonetheless, during the course of the 160 mile journey, one of the detectives gave what has come to be known as the "Christian burial speech," which, playing on Williams' religious beliefs, induced his confession as to the location of the body. Despite the fact that the case was appealed on Miranda grounds, that the lower court rulings specifically rehed on Miranda, and that the amicus curiae briefs of twenty-two states urged the overturning of Miranda, the Court excluded the evidence on sixth amendment grounds, holding that Williams had not waived his right to counsel. Id. at 39798. The Court thus evidenced a reluctance to rely on Miranda in a seemingly obvious fifth amendinent case. See Kamisar, Brewer v. Williams, Massiah, and Miranda: What is "Interrogation"? When Does it Matter?, 67 GEO. L.J. 1, $69-79$ (1978) [hereinafter cited as What is "Interrogation"?]; Comment, The Declining Miranda Doctrine: The Supreme Court's Development of Miranda Issues, 36 WASH. \& LeE L. REv. 259, $273-74$ (1979) [hereinafter cited as The Declining Miranda Doctrine].

37. See Stone, supra note 35, at 100-01 \& n.6. Stone cites United States v. Washington, 431 U.S. 181 (1977); United States v. Wong, 431 U.S. 174 (1977); Oregon v. Mathiason, 429 U.S. 492 (1977); Doyle v. Ohio, 426 U.S. 610 (1976) (evidence inadmissible on other grounds); United States v. Mandujano, 425 U.S. 564 (1976); Beckwith v. United States, 425 U.S. 341 (1976); Baxter v. Palmigiano, 425 U.S. 308 (1976) (adverse inference permitted to be drawn from prisoner's silence at prison disciplinary proceedings); Michigan v. Mosley, 423 U.S. 96 (1975); Oregon v. Hass, 420 U.S. 714 (1975) (statements admitted for impeachment purposes ouly); Michigan v. Tucker, 417 U.S. 433 (1974); and Harris v. New York, 401 U.S. 222 (1971) (statements admitted for impeachment purposes only). Since 1977, the Court has limited the application of Miranda in three more cases: Rhode Island v. Innis, 446 U.S. 291 (1980); Fare v. Michael C., 442 U.S. 707 (1979); and North Carolina v. Butler, 441 U.S. 369 (1979).

Other statistics are equally revealing, including the remarkably disproportionate number of cases granted certiorari where the government was appealing a holding of imadmissibility under Miranda, as compared with those where the defendant was appealing a holding of admissibility. Stoue, supra note 35, at 100.

38. See Tague v. Louisiana, 444 U.S. 469 (1980) (per curiam).

39. E.g., United States v. Washington, 431 U.S. 181 (1977); Michigan v. Tucker, 417 U.S. 433 (1974); see Stone, supra note 35, at 168.

Even Cougress has attempted to reinstate the voluntariness standard by legislatively overruling Miranda. See 18 U.S.C. § 3501 (1976). This section, more commonly known as Title II of the 1968 Crime Control Act, attempted to revive the traditional due process analysis of confessions that had beeu specifically rejected in Miranda. Questions as to the law's constitutionality arose during debates on the bill, but apparently it was thought that by the time the law's constitutionality was challenged, the composition of the Court would have changed so that Miranda could no louger command a majority. See S. REP. No. 1097, 90th Cong., 2d Sess. 51, reprinted in [1968] U.S. CoDe Cong. \& AD. News 2112, 2137-38.

Although the statute remains intact, it has received hittle judicial attention and has created hittle controversy. The conflict between Miranda and $\S 3501$ has generally been resolved by iguoring the latter. See, e.g., Ailsworth v. United States, 448 F.2d 439, 441 (9th Cir. 1971). On this conflict in general, see Gandara, Admissibility of Confessions im Federal Prosecutions: Implementa- 
The Burger Court has further diluted Miranda's influence by refusing to adopt per se rules that would exclude evidence obtained in violation of the spirit of Miranda. In Michigan v. Mosley, ${ }^{40}$ the Court held that to reinterrogate a suspect is not a violation of the right to remain silent as long as the invocation of that right is "scrupulously honored." ${ }^{\prime 41}$ Rejecting a per se prohibition on further interrogation, the Court maintained that such a rule would turn the Miranda safeguards into "wholly irrational obstacles to legitimate police investigative activity, and deprive suspects of an opportunity to make informed and intelhigent assessments of their interests." ${ }^{42}$ In North Carolina v. Butler, ${ }^{43}$ the Court went on to narrow the Miranda holding by rejecting the contention that Miranda required an explicit waiver for a confession to be admissible. It held that in soine cases a valid waiver can be "inferred from the actions and words of the person interrogated."44

It is thus fairly clear that until Edwards, the present Court did not endorse the contention in Miranda that only objective guidelines can adequately protect a suspect's fifth ainendinent rights. ${ }^{45}$ Moreover, the Court seriously questioned the soundness of Miranda as a whole. It was against this background that the Burger Court addressed the question of whether reinterrogation ought to be allowed after the exercise of the right to counsel. Twice before it had specifically declined to reach the issue. ${ }^{46}$ To ignore it once again would confirm the Court's skcptical view of Miranda.

\section{III \\ ANALYSIS \\ A. Creating a Per Se Rule}

The Court held that Edwards had not validly waived his right to counsel, notimg that the Arizona Supreine Court's reliance on voluntariness as the standard for waiver was erroneous. ${ }^{47}$ This alone would

tion of Section 3501 by Law Enforcement Officials and the Courts, 63 GEo. L.J. 305, 305-07, 313 (1974); Schrock, supra note 36; Comment, Police Interrogation of Suspects: The Court versus the Congress, 57 CALIF. L. REv. 740 (1969). See generally Friendly, The Constitution, in "EQuAL JUSTICE UNDER LAw" 1 (1977); Letter to the Editor from Herbert Wechsler, N.Y. Times, June 16, $1968, \S 4$, at E-17, col. 3.

40. 423 U.S. 96 (1975).

41. Id. at 104 .

42. Id. at 102 .

43. 441 U.S. 369 (1979).

44. Id. at 373.

45. See id. at 377-78 (Brennan, J., dissenting); Michigan v. Mosley, 423 U.S. at 114-15 (Brennan, J., dissenting).

46. See Rhode Island v. Innis, 446 U.S. 291, 298 n.2 (1980); Brewer v. Williams, 430 U.S. 387, $397-98$ (1977).

47. $101 \mathrm{~S}$. Ct. at $1883-84$. 
have been sufficient grounds for overturning Edwards' conviction. Beyond reiterating the standard of knowing and intelligent waiver, however, the Edwards Court added an "additional safeguard" to ensure that the right to counsel, once exercised, is effectuated. When a suspect now invokes his right to counsel, he is not subject to further interrogation by authorities until counsel is provided, unless the suspect initiates the dialogue with the law enforceinent officers. ${ }^{48}$

While Edwards' message to law enforcement agencies is fairly clear, ${ }^{49}$ the directive to reviewing courts is less certain. This ambiguity is highlighted by Justice Powell's concurrence, where two possible readings of the majority opinion were offered, one of which was the creation of a per se rule. ${ }^{50}$ The opinion of the Court never expressly characterizes the rule as such. Nonetheless, there are several reasons that suggest that Edwards ought to be interpreted as creating a per se rule proscribing any interrogation of an accused who has invoked his right to counsel.

First, the Edwards Court expressly based its decision on Miranda, ${ }^{51}$ and the opinion accordingly should be read in light of $M i$ randa's principles. The Miranda holding is based on the preinise that only through objective guidelines can a suspect's rights during custodial interrogation be protected. ${ }^{52}$ A per se rule is therefore consistent with the spirit of Miranda, for sucl1 a rule uses objective criteria to determine whether the evidence obtained slould automatically be excluded. ${ }^{53}$ The Edwards opinion specifically mandates that it be the suspect who initiates any subsequent interrogation. The implication that the absence of this objectively determined factor will result in automatic exclusion follows logically from the Court's stateinent that any finding of a valid waiver must include "the necessary fact that the ac-

48. Id. at 1885. This approach is suggested by the American Law Institute, see ALI MODEL Code of Pre-Arraignment Procedure, \& I40.8 (1975) [hereinafter cited as Model Code], and has been followed for quite some time by California courts. The leading case is People v. Fioritto, 68 Cal. 2d 714, 441 P.2d 625, 68 Cal. Rptr. 817 (1968). See People v. Pettingill, 21 Cal. 3d 231, 578 P.2d 108, 145 Cal. Rptr. 861 (1978); People v. McDaniel, 16 Cal. 3d 156, 545 P.2d 843, 127 Cal. Rptr. 467, cert. denied, 429 U.S. 847 (1976); Comment, Waiver of Rights in Police Interrogations: Miranda In the Lower Courts, 36 U. CHI. L. REv. 413, 437-41 (1969) [hereinafter cited as Waiver of Rights in Police Interrogations].

49. See generally text accompanying notes 67-69 infra.

50. $101 \mathrm{~S}$. Ct. at 1887 (Powell, J., concurring).

51. Id. at $1883-85$.

52. 384 U.S. at 457-63.

53. See, e.g., Manson v. Brathwaite, 432 U.S. 98, 109-13 (1977); Miranda v. Arizona, 384 U.S. at $444,478-79$.

The alternative reading of Edwards offered by Justice Powell involved a totality of the circumstances standard, with a heightened focus on the question of who initiated the conversation subsequent to the suspect's request for counsel. Such an approach necessarily involves a more subjective judgment, and to this extent, is less consistent with the Miranda principles that are the foundation of the majority opinion. 
cused, not the police, reopened the dialogue with the autliorities." 54

Moreover, the Court specifically distinguisled Michigan v. Mosley - a case whicli rejected a per se rule in the right to silence contextfor the purpose of establishing a different standard of waiver in right to counsel cases. In Mosley, the Court refused to apply a per se rule against interrogation subsequent to the exercise of the right to silence. The Mosley Court contended that the Miranda authors lad not indicated when interrogation of the suspect nnay resume when he invokes only his right to silence. ${ }^{55}$ Yet Mosley noted that Miranda seemingly prohibited any further interrogation after the exercise of the right of counsel until the suspect's attorney arrived. ${ }^{56}$ Edwards, a right to counsel case, is therefore the logical extension of Mosley. The Court turned the dictum of Mosley into the lolding of Edwards.

Finally, the conclusion that Edwards sets out a per se rule is reinforced by noting the other plausible rationales on which the Court could have based its suppresssion of Edwards' confession. First, the Court could have applied the rule set out in Mosley and held that Edwards' invocation of his right to remain silent had not been "scrupulously honored."57 Second, despite the fact that Mosley explicitly distinguished between the invocation of the right to counsel and the right to silence, ${ }^{58}$ the Court could have applied the rule in Mosley to both rights by holding that Edwards' invocation of his right to counsel was not scrupulously honored. ${ }^{59}$ Third, the Court could have found

54. $101 \mathrm{~S}$. Ct. at $1885 \mathrm{n} .9$ (emphasis added).

55. 423 U.S. at 101.

56. Id. at 100-01 (dictum). Justice White, concurring, explicitly asserted that Miranda erected a per se rule against further interrogation once a suspect asks for counsel. Id. at 109-10.

57. Although Mosley failed to provide concrete guidelines as to what this standard will require, see Stone, supra note 35, at 134-35; The Declining Miranda Doctrine, supra note 36, at 268, the critical factors in that case were that the reinterrogation had occurred inore than two hours after Mosley invoked his privilege, that it was conducted by a different officer and concerned an unrelated crime, and that it was preceded by fresh Miranda warnings. See 423 U.S. at 104-05. Very few, if any, of these factors are present here. Edwards told the officer he wanted an attorney before making a deal. The next day he indicated that he did not wish to speak to anyone. And although he was given fresh warnings, he was immediately interrogated concerning the very same crime. On these facts, therefore, it would not be difficult to find that Edwards' invocation of his right to silence was not scrupulously honored.

In light of Michigan v. Tucker, 417 U.S. 433 (1974), the Court might have to give consideration to the question of whether this was a violation of the privilege against self-incrimination or of the procedural safeguards set out in Miranda. If the latter, the issue would be "how swceping the judicially imposed consequences of this disregard shall be." Id. at 445. See The Declining Miranda Doctrine, supra note 36, at 368-69. But given that Tucker was in fact decided on very narrow grounds, see 417 U.S. at 447, it is unlikely that it would have undermined any holding based on Mosley. See Note, Criminal Procedure-Michigan v. Mosley: A New Constitutional Procedure, 54 N.C. L, REv. 695, $702-03$ (1976).

58. 423 U.S. at 101 n.7.

59. This has been the approach of at least one circuit court. See United States v. Nixon, 571 F.2d 1121, 1121 (9th Cir. 1978) (citing Michigan v. Mosley). 
that Edwards' sixth amendment rights as construed in Massiah v. United States ${ }^{60}$ and Escobedo v. Illinois ${ }^{61}$ had been violated when incriminating statements were taken during "adversary judicial proceedings" in the absence of counsel. ${ }^{62}$ Finally, a fourth possible holding was that favored by Chief Justice Burger, namely that on these facts, the government had simply not carried its heavy burden of proof of a valid waiver. ${ }^{63}$

Each of these alternatives would stop short of a per se rule and would maintain the totality of the circumstances as the sole standard adjudging the validity of waivers. More noticeably, each would limit the Court's holding to the facts of this case. Against this background, it is significant that the Court chose to go beyond the facts of this case and set down a rule of general application, where in all cases the invocation of the right to counsel immediately triggers special protections. To lend substance to the importance of that right within the context of custodial interrogation, the Court found it necessary to go beyond existing law and to articulate a clear and meaningful prohibition on further interrogation after the right to counsel is invoked. The implication was that a new per se rule for the protection of suspects had been established.

\section{B. Why a Per Se Rule?}

One can only speculate as to the Court's motivations for implementating the per se rule that it has steered away from in the past. The Court apparently believed that the traditional totality of the circumstances standard was simply insufficient to protect the suspect who invokes his right to counsel during custodial interrogation. Although the Court did not articulate the advantages of a per se rule, sucl a rule is indeed preferable to the totality of the circumstances approach in the context of protecting Miranda rights.

As a general matter, per se rules allow the Court to establish clear guidelines for lower courts to follow. They do so by creating a thresh-

60. 377 U.S. 201 (1964).

61. 378 U.S. 478 (1964).

62. The Court could have held that "adversary judicial proceedings" against Edwards had begun, since the process had shifted "from investigatory to accusatory when its focus [was] on the accused and its purpose [was] to elicit a confession." Escobedo v. Illinois, 378 U.S. at 492 . Such a holding would not have been noticeably different from that in Brewer v. Williams, 430 U.S. 387 (1977), and would have found substantial support among commentators. See, e.g., What is "Interrogation"?, supra note 36, at 80-83; Traynor, The Devils of Due Process in Criminal Detection, Detention, and Trial, 33 U. CHI. L. REv. 657, 673 (1966).

63. Viewing the "totality of the circumstances," see Johnson v. Zerbst, 304 U.S. 458, 464 (1938), particularly the fact that Edwards was told that "he had to" speak with the detectives immediately after refusing to talk to anyone, the Chief Justice believed that the resumption of questioning was not the product of a voluntary waiver. $101 \mathrm{~S}$. Ct. at 1887 (Burger, J., concurring). 
old question of fact, such as whether a Miranda warning was given or whether the right to counsel was invoked. From the resolution of this question flows a conclusion of law. The alternative, which is to require a case-by-case approach, fails to generate meaningful precedent for lower courts to employ. ${ }^{64}$ This in turn leads to imconsistent results based on virtually indistimguishable facts. ${ }^{65}$ To the extent that a per se rule brings about uniform rulings in such situations, it serves the judicial system well. Moreover, it benefits courts individually by freeing them from the "difficult and troublesome necessity of adjudicating in each case whether coercive influenccs, psychological or physical, had been employed to secure admissions or confessions." 66

A second advantage of per se rules follows logically from the first. To the extcnt that the Court estabhishes clear guidelines for lower courts to follow, it more effectively serves to deter police misconduct. Ad hoc determinations ouly provide rulings as to police behavior in the specific factual settings before the Court. Objectionable coercive tactics are not identified im general terms, and thus such opinions fail to prohibit certam categories of pohice behavior altogether. Absent such blanket prohibitions, police are likely to legitimize any effcctive tactic not expressly banned, and to "push to the limit" any constitutional restramt on their actions. ${ }^{67}$ Studies completed after Miranda indicate

64. This is demonstrated by the Court's opinion in Mosley. Although the Court established the "scrupulously honored" standard for compliance with the exercise of the right to silence, it conspicuously failed to delineate guidelines for lower courts to employ in implementimg that standard. See Stone, supra note 35, at 134-35; The Declining Miranda Doctrine, supra note 36, at 268.

65. Compare United States v. Hernandez, 574 F.2d 1362 (5th Cir. 1978) (statements obtained from defendant lield incommunicado for five loours with police making frequent interrogation attempts ruled inadmissible) and United States v. Olof, 527 F.2d 752 (9th Cir. 1975) (statements obtaimed from defendant after being reinterrogated three hours later and being presented with an unpleasant description of prison life ruled imadmissible) with Williams v. Ohio, 547 F.2d 40 (6th Cir. 1976), cert. denied, 435 U.S. 998 (1978) (statements obtained from defendant after being reinterrogated for a third time within five hours and confronted by a fellow suspeet willing to confess ruled admissible) and Uuited States v. Koch, 552 F.2d 1216 (7th Cir. 1977) (statements obtaimed fron defendant in the absence of counsel six hours after refusal to speak and immediately after refusal to sign waiver of rights form not ipso facto madmissible).

A second consequence may be a lessening of appellate review because findings of fact are difficult to overturn. See Note, Michigan v. Mosley: A New Constitutional Procedure, 54 N.C. L. REv. 695, 704 (1976). "Consequently, the courts will, in all probability, adinit confessions taken under conditions more coercive than those that existed in Mosley." Id.

66. Pcople v. Fioritto, 68 Cal. 2d 714, 717, 441 P.2d 625, 626, 68 Cal. Rptr. 817, 818 (1968).

67. Irvine v. Califorma, 347 U.S. 128, 138-39 (1954) (Clark, J., concurring); see Kamisar, $A$ Dissent from the Miranda Dissents: Some Comments on the "New" Fifh Amendment and the Old "Voluntariness" Test, 65 Mich. L. Rev. 59, 94-104 (1966) [hereinafter cited as A Dissent]; White, Police Trickery in Inducing Confessions, 127 U. PA. L. Rev. 581, 598 (1979).

The Miranda Court quoted from a widely used police manual explaining the tcchnique to be used when a suspect attempts to invoke his right to counsel:

[T] he interrogator sliould respond by suggesting that the subject first tell the truth to the imterrogator himself rather than get anyone else involved in the matter. If the request is for an attorney, the interrogator may suggest that the subject save himself or his family 
that despite having to give warnings, police are still able to induce the suspect to waive his right to counsel, ${ }^{68}$ or to obtain a confession before the suspect's attorney has arrived at the police station. ${ }^{69}$ The continuation of police practices that subvert the goals of Miranda underscores the need for a more stringent standard for waiver.

Perhaps the most meaningful advantage of a per se rule in the area of confessions is that it precludes ineffective subjective inquiry by courts and ensures that a suspect's decision to speak is "truly the product of free choice."70 The voluntarily, intelligently, and knowingly made waiver test often fails to account for the coercion inherent in custodial interrogation. ${ }^{71}$ Moreover, it places a lieavy burden on the defendant to rebut the testimony of authorities that he knowingly and intelligently waived his rights, for the defendant is often inadequately equipped to present evidence on his behalf. ${ }^{72}$ These concerns more than likely contributed to the Court's opinion in Edwards.

Beyond these traditional rationales for implementing per se rules, it was apparent that the Edwards court was especially concerned with the importance of counsel for the protection of fifth amendment rights. Miranda first articulated this concern, emphasizing that "the right to have counsel present at the interrogation is indispensable to the protection of the Fifth Amendment privilege." 73 Later, Justice White, concurring in Mosley, noted that scrupulously honoring the right to counsel may not be sufficient protection for the accused who acknowledges that "he is not competent to deal with the authorities without legal advice."74 In more general terms, the Brewer Court stressed the imdispensability of the right to counsel "to the fair administration of

the expense of any such professional service, particularly if he is innocent of the offense under investigation. The interrogator may also add, "Joe, I'w only looking for the truth, and if you're telling the truth, that's it. You can handle this by yourself."

384 U.S. at 454 (quoting F. INBaU \& J. ReId, Criminal InterRogation and Confessions 112 (1962)).

68. See Leiken, Police Interrogation in Colorado: The Implementation of Miranda, 47 DEN. L.J. 1, 26-34 (1970).

69. See Medalie, Zeitz \& Alexander, Custodial Police Interrogation in our Nation's Capital: The Attempt to Implement Miranda, 66 MiCH. L. REv. 1347, 1394-95 (1968).

70. Miranda v. Arizona, 384 U.S. at 457.

71. See Kamisar, A Dissent, supra note 67, at 94-104; The Declining Miranda Doctrine, supra note 36 , at 275 .

72. Pye, Interrogation of Criminal Defendants-Some Views on Miranda v. Arizona, 35 FordhaM L. Rev. 199, 214-15 (1966). See Miranda v. Arizona, 384 U.S. at 475.

73. 384 U.S. at 469 . The Court also noted several "subsidiary" functions of the presence of counsel, mcluding mitigating against untrustworthiness, protecting against unfair police practices, and enhancing the fact-finding process. Id. at 470. See Escobedo v. Illinois, 378 U.S. at 490.

74. 423 U.S. at 110 n.2 (White, J., concurring). Justice White was to echo these sentiments at the oral arguments for Edwards. There he inquired, "What about the right to an attorney? The invocation of that right in essence acknowledges one's own incompetence to deal with the situation without expert help." 28 CRIM. L. REP. (BNA) 4081 (Nov. 12, 1980). 
our adversary system of criminal justice."75 Edwards' steadfast honoring of the right to counsel was therefore concomitant protection of the otherwise vulnerable right to be free from self-mcrimination.

Before $E d w a r d s$, the Court protected the right to counsel by virtue of strict standards for waiver. It refuscd to presume a waiver where the record was silent or simply from the defendant's failure to affirmatively request counsel. ${ }^{76}$ Under Zerbst, the Court required that the waiver be "an intentional relinquishment or abandonment of a known right."77 In Miranda, the Court sought to give this requirenent effect by placing a "heavy burden" on the government to demonstrate that the waiver was voluntary, knowing and intelligent. ${ }^{78}$ And most recently im Brewer v. Williams, the Court reiterated the high standard for waiver of the right to counsel. ${ }^{79}$ Consistent throughout these opmions has been the recognition that waiver of rights is not a preliminary ritual to imterrogation, but is fundamental to the fifth amendment privilege.

Dcspite the rhetoric, however, the reality remains that in practice, the "heavy burden" has not been very heavy ${ }^{80}$ Many lower courts have equated the Court's requirement of a "voluntary, knowing and imtelligent" waiver with the pre-Miranda "voluntariness" test. ${ }^{81}$ Where an inevitable credibility contest between suspcct and police is involved, the waiver standard necessary to ensure the "indispensability" of counsel during interrogation is undermined. ${ }^{82}$ And this is all thc inore the case where the police have effectively mastered techmiques "to induce the suspect to waive his right to counsel while at the saine time obtaining sufficient evidence to prove that the waiver was "knowing and intelligent." "83 As a result, a need arose for "secondary" protection of the right to counsel, namely, for a stricter standard of waiver. Therefore, the Edwards Court chose to buttress the effectiveness of the right

75. 430 U.S. at 398. (1962)

76. E.g., id. at 387; Escobedo v. Ullinois, 378 U.S. at 478; Carnley v. Cochran, 369 U.S. 506

77. Johnson v. Zerbst, 304 U.S. 458,464 (1938).

78. 384 U.S. at 475.

79. 430 U.S. at $404-06$.

80. See Model CoDE, supra note $48, \S 140.8$, commentary at 367-68.

81. See Waiver of Rights in Police Interrogations, supra note 48, at 447.

82. See MODEL CODE, supra note $48, \& 130.4$, commentary at 346 , where the reporter states that "reliance upon the oral testimony of the officer to establish the conditions of interrogation will often lead to a swearing contest between the police officer and the suspect, a contest which the suspect will rarely win, whether he is telling the truth or not."

83. Leiken, supra note 68, at 27 (citations omitted). Shortly after Miranda was implemented, a study of interrogations in New Haven concluded: "As long as the police question the suspect alone, lie is no match for them. The suspect will not grasp firmly his rights. He will try to deal with his captors, to talk his way out, and he is enormously inadequate to that task." Project, Interrogations in New Haven: The Impact of Miranda, 76 Yale L.J. 1519, 1614 (1967) [hereinafter cited as Interrogations in New Haven]; see notes 67-72 and accompanying text supra. 
to counsel during custodial interrogation with a per se rule restricting its waiver once that right has been invoked. ${ }^{84}$

Critics of a per se rule contend that it works to "imprison a man in his privileges"85 by depriving him of the opportunity to intelligently assess his own interests. ${ }^{86}$ Presuniably the fear is that rules such as that in Edwards will preclude a suspect from speaking with the authorities after he has imvoked his right to counsel. But it is unclear how the particular per se rule enunciated in Edwards can serve to "imprison a man in his privileges," smce it exphicitly permits the suspect to change his mind and submit to imterrogation if he so chooses. ${ }^{87}$ The per se aspect of the holding merely ensures that if a suspect does waive his rights, it was because he changed his mind, and not because the officers changed it for him. ${ }^{88}$

Finally, the Court's affirmation of a per se rule reflects the fact that einpirical data has failed to confirm the behef that the costs of strong constitutional safeguards greatly exceed the benefits. ${ }^{89}$ Just eight years before Miranda, the Court rejected the per se rule it was to adopt in Edwards, believing that such a rule "would have a ... devastating effect on enforcement of criminal law, for it would effectively preclude police questioning - fair as well as unfair-until the accused was afforded opportunity to call his attorney." Miranda, Justice White believed that the new rules would prevent in-

84. Indeed many commentators have argued that the goals of Miranda demand an even stricter rule, one that would prohibit any waiver of Miranda rights without the advice of counsel. See, e.g., Kamisar, $A$ Dissent, supra note 67, at 67 \& n.47; Leiken, supra note 68, at 46-51; Interrogations in New Haven, supra note 83, at 1613-16. Although the Court has steadfastly refused to accept such an interpretation, see, e.g., Faretta v. California, 422 U.S. 806 (1975); Brewer v. Wilhams, 430 U.S. at 410 (Powell, J., concurring); Michigan v. Mosley, 423 U.S. at 110 (White, J., concurring), its decision to implement a stricter standard of waiver for the right to counsel than the one presently used was a significant step in that direction.

85. Adams v. United States ex rel. McCann, 317 U.S. 269, 280 (1942).

86. See, e.g., Edwards v. Arizona, 101 S. Ct. at 1888 n.l (Powell, J., concurring); Michigan v. Mosley, 423 U.S. at 108-09 (White, J., concurring).

87. If the suspect changes his mind and "initiates" the communication with the police, the Edwards rule allows the police to renew questioning of the suspect. See $101 \mathrm{~S}$. Ct. at 1884-85.

88. See People v. Fioritto, 68 Cal. 2d 714, 719-20, 441 P.2d 625, 627-28, 68 Cal. Rptr. 817, 819-20 (1968). In Brewer v. Williams, Justice Powell appeared to endorse this approach:

[T] he right to assistance of counsel may be waived, after it has attached, without notice to or cousultation with counsel. We would have such a case here if petitioner had proved that the police officers refrained from coercion and interrogation, as they had agreed, and that Williams freely on his own initiative had confessed the crime.

430 U.S. at 413 (Powell, J., concurring) (einphasis added) (citations omitted).

89. Shortly after Miranda was handed down, the then Attorney General of California predicted that the decision would have a "tremendous impact on pohice practices." Lynch, Interrogations of Criminal Defendants-Some Views on Miranda v. Arizona, 35 FordHAM L. REv. 221, 221 (1966). To the same effect, see the remarks of Brooklyn District Attorney Aaron Koota in N.Y. Times, Aug. 13, 1966, at 1, col. 1.

90. Crooker v. California, 357 U.S. 433, 441 (1958). 
terrogations, reduce the number of confessions and guilty pleas, and increase the judiciary's workload.91

Since the decision in Miranda, however, numerous einpirical investigations have disproved the fear that Miranda warnings would stifle talking to authorities and that information essential to obtaining convictions would be lost. ${ }^{92}$ These studies consistently concluded that beyond provoking the wrath of police, Miranda has had little practical impact. ${ }^{93}$ Despite the giving of warnings, most suspects continued to waive their rights. ${ }^{94}$ Likewise, the number of convictions remained generally, unchanged, since in only a small minority of cases were the confessions deemed essential. ${ }^{95}$ Moreover, with respect to the right to counsel, the studies came to similar conclusions. They showed that suspects often do not request counsel ${ }^{96}$ and readily waive their right to obtam one. ${ }^{97}$ Moreover, many suspects do not follow the advice of their counsel and speak with police even after being told not to. ${ }^{98}$

To at least some extent, then, the absence of stricter standards for waiver has taken its toll on important constitutional rights. Faced with this trade-off, the conclusion seemed inescapable. Whereas the "cost" of procedural safeguards has in practice been negligible, the corresponding "benefit" of effectuating constitutional principles is great indeed. Viewed in these terms, a per se rule to protect the right to counsel is a bargain the Court would have been hard put to pass up.

\section{Applying the Per Se Rule}

While a per se rule is readily drawn from the opinion, the parameters of its application are more problematic. The Court established a new rule for determining the validity of a waiver, yet cited the traditional Zerbst test approvingly. ${ }^{99}$ In fact, the Edwards rule and the

91. 384 U.S. at 533,541 (White, J., dissenting).

92. E.g., Leiken, supra note 68; Medalie, Zeitz \& Alexander, supra note 69; Seeburger \& Wettick, Miranda in Pittsburgh-A Statistical Study, 29 U. PITT. L. Rev. 1 (1967); Stephens, Flanders \& Cannon, Law Enforcement and the Supreme Court: Police Perceptions of the Miranda Requirements, 39 TENN. L. REv. 407 (1972); Younger, Interrogation of Criminal Defendants-Some Views on Miranda v. Arizona, 35 Fordham L. Rev. 255 (1966); Interrogations in New Haven, supra note 83.

93. See Stephens, Flanders \& Cannon, supra note 92, at 429; Interrogations in New Haven, supra note 83, at 1615-16. 63.

94. See Leiken, supra note 68, at 46-49; Interrogations in New Haven, supra note 83, at 1562-

95. See N. Sober, The New Confessions Standard-Miranda r. ARizona 136-50

(1966); Younger, supra note 92, at 260-62; Interrogations in New Haven, supra note 83, at 1613.

96. See Medalie, Zeitz \& Alexander, supra note 69, at 1352.

97. See Leiken, supra note 68, at 27-29; Interrogations in New Haven, supra note 83, at 156263,1600 .

98. See Interrogations in New Haven, supra note 83, at 1605.

99. $101 \mathrm{~S}$. Ct. at $1883-84$. 
Zerbst standard will both apply. Thus, when employing Edwards to evaluate the admissibility of a statement made after a request for counsel, there are several distinct inquiries.

First, the trial court must decide whether there was in fact an " $\mathrm{m}$ terrogation" after the suspect requested counsel. As the Court noted, ${ }^{100}$ this question is governed by the recent case of Rhode Island $v$. Innis. ${ }^{101}$ There the Court's definition of interrogation included not only express questioning, but also "any words or actions on the part of the police that the pohice should know are reasonably likely to elicit any incriminating response froin the suspect."102 Thus, if the police return to a suspect's cell and initiate further questioning, the Edwards rule will come into play. Any subsequent confession is inadmissible. Similarly, where the police action is the functional equivalent of questioning, such as making accusatory staternents in the presence of the suspect, it is also characterized as interrogation. ${ }^{103}$

There will often be difficult issues to resolve on the interrogation question. Two questions in particular seem likely to arise: whether the police may ask the suspect if he has changed his mind about talking and whether the police may confront the suspect with the evidence agamst him. ${ }^{104}$ At first glance, asking the suspect if he has changed his mind inay not seem to be questioning "likely to elicit any incriminating response." However, such questioning is indicative of the sort of subtle coercion that Miranda sought to counteract. ${ }^{105}$ Moreover, it was $E d$ wards' directive that any change of mind should first be voiced by the suspect and not be prompted by the authorities. Thus, such questioning should be considered "interrogation." Moreover, it is difficult to conceive of any motive on the part of the police for asking this question other than the hope of obtaming incriminating statements. For the same reasons, it seems clear that confronting the suspect with incriminating evidence is behavior "Tikely to elicit an incriminating response." 106 In fact, this is its avowed purpose. ${ }^{107}$ Therefore, these

100. Id. at 1885 .

101. 446 U.S. 291 (1980).

102. Id at 301.

103. See, e.g., United States v. Jordan, 557 F.2d 1081 (5th Cir. 1977) (statement by officer directly to individual stopped for license clreck that officer had information the nudividual had a shotgun in the car was interrogation for the purposes of Miranda). Cf. Brewer v. Williams, 430 U.S. at $399-400$ (Although the facts of Brewer illustrate a classic example of subtle coercion, see note 36 supra, the Court later distinguished "interrogation" while in custody from "interrogation" in the sixth amendment context, Rhode Island v. Innis, 446 U.S. at 300 n.4).

104. See Edwards v. Arizona, 101 S. Ct. at 1888 (Powell, J., concurring).

105. See Miranda v. Arizona, 384 U.S. at 448-55.

106. Although a tenable argument can be made that presenting the suspect with evidence against him is necessary for an informed and intelligent decision as to the exercise of his rights, see, e.g., Michigan v. Mosley, 423 U.S. at 109 n.1 (White, J., concurring), this argument in fact 
forms of elicitation should be categorized as "interrogation."

If it is determined that there has been an interrogation, or reinterrogation as the case may often be, the inquiry then focuses on whether the suspect "initiated" the communication, exchanges or conversations witl the police. ${ }^{108}$ This second step in the analysis is likely to be inore problematic since the Court has not defined what constitutes "initiation." Thus, it is unclear how Edwards will be applied to a case where the suspect asks about the evidence against him, the fate of possible coconspirators, or the duration of his detention.

Consider the following lypotletical: a suspect calls out for a police officer and asks how long he can expect to be in jail. The officer responds by asking: "Now that you know we have your partners locked up, and we have found the body, don't you want to talk and get this whole thing over with?"

As discussed above, the officer's response constitutes interrogation. It appears, lowever, as though the suspect "initiated" the exchange. To define "initiation" so literally would lose sight of the underlying goal of $E d w a r d s$. The determinative factor is whether the suspect has changed his mind as to speaking to the authorities before seeing an attorney. In the example, the suspect did not invite further interrogation, but asked only low long he would be in jail. To satisfy the purposes of $E d w a r d s$, the officer's entreaty to speak should be considered the initiation of a new conversation. The officer clearly went beyond the scope of the suspect's request: his response was anything but neutral, for its purpose was to ehcit an incriminating response from the suspect. ${ }^{109}$ In hight of Miranda's underlying goal of counteracting the coerciveness of custodial interrogation, courts ought to be partieularly cautious in construing "initiation" so hiterally. Such an approach would be inconsistent with Edwards' inandate that it be the suspect who changes his mind, and not the authorities who change it for him.

If the per se rule does not apply, there being no interrogation or police-initiated dialogue, then Edwards nakes it clear that the Zerbst test will be used to determine the validity of the waiver. ${ }^{110}$ That is, the government still carries the burden of showing a voluntary, knowing

cuts both ways. See Stone, supra note 35, at 137 n.204; Waiver of Rights in Police Interrogations, supra note 48 , at 441 .

107. See, e.g., United States v. Barnes, 432 F.2d 89, 91 (9th Cir. 1970).

108. $101 \mathrm{~S}$. Ct. at 1885.

109. See United States v. Bennett, 626 F.2d 1309 (5th Cir. 1980) (officer's natural exclamation in response to seeing a gun and with no expectation of eliciting a response from the defcndant not "interrogation"); Lynes v. Scully and Abrams, No. 81-783, slip op. (S.D.N.Y. July 9, 1981) (no "interrogation" where officer's comment was neutral and did not call for any response from defendant).

110. $101 \mathrm{~S}$. Ct. at $1883-85$ n.9. 
and intelligent waiver. Thus, Edwards requires two preliminary, and often determinative, inquiries but does not supplant the traditional totality of the circumstances standard.

\section{The Potential Impact of Edwards}

The Court's adoption of a per se approach to protecting a suspect's rights represents a significant departure from the post-Miranda trend, marked by the Court's numerous decisions narrowly construing $M i$ randa's view of fifth amendment safeguards. It is thus likely that $E d-$ wards will curtail the application of several recent cases using subjective tests in the areas of right to silence and right to counsel.

Edwards will likely limit the application of Mosley's "scrupulously honored" test to those cases where only the right to silence was invoked. Mosley expressly stated that it did not address the procedures to be followed when the suspect asks to consult with a lawyer. ${ }^{111}$ The Court thus left open the possibility of applying the "scrupulously honored" standard to the invocation of the right to counsel.112 One circuit court, relying on the spirit of Mosley, applied the "scrupulously honored" test to the defendant's request for counsel. ${ }^{113}$ Edwards rejected this approach, in effect stating that the only way this right can be scrupulously honored once invoked is to prohibit any further interrogation altogether.

$E d w a r d s$ thus raises a presumption that renewed interrogation at the instance of the authorities is inherently coercive. This premise is at odds with Mosley where a suspect's right to silence was considered scrupulously honored despite renewed questioning after that right had been invoked. Varying the presumption as to coercion on the basis of the right invoked seems inconsistent with Miranda. ${ }^{114}$ To this extent, the presumption underlying Miranda and reaffirmed in Edwards suggests that Mosley, in principle, ought to be overruled.

As a practical matter, however, the use of a per se rule to protect the right to silence would lead to undesirable results. It would result in an absolute and permanent prohibition of police-initiated inquiry. Applying a per se rule to the right to counsel, on the other hand, only terminates interrogation until the suspect's attorney arrives. ${ }^{115}$ Given

111. 423 U.S. at 101 n.7.

112. See The Declining Miranda Doctrine, supra note 34, at 268.

113. See United States v. Nixon, 571 F.2d 1121 (9th Cir. 1978); United States v. RodriguezGastelum, 569 F.2d 482 (9th Cir. 1978); United States v. Pheaster, 544 F.2d 353, 366-68 (9th Cir. 1976).

114. See Stone, supra note 35, at 135-36; Note, Michigan v. Mosley: A New Constitutional Procedure, 54 N.C. L. REv. 695, 704-05 (1976).

115. Justice Powell's claim that a per se rule in either situation would create a permanent immunity from subsequent imterrogation, see Edwards v. Arizona, $101 \mathrm{~S}$. Ct. at 1887-89 (Powell, 
its unlimited restraint, a per se rule in the right to silence context might be fairly characterized as a "wholly irrational obstacle to police investigative activity" that the Court has been careful not to erect. ${ }^{116}$

From this perspective, Edwards and Mosley can both be viewed as logically consistent with Miranda and with each other. Both maintain the same high standard for a voluntary, knowing and intelligent waiver of fifth amendment rights required by Miranda. And botll strive to ensure that the suspect who invokes his rights will be free froin coercive attempts to change his mind. The analytical frameworks vary, not because the value or importance of the rights is different, but because the realities of impleinenting them are not the saine.

Edwards will surely limit the application of North Carolina v. Butler's $s^{117}$ implied waiver standard by proscribing any waiver of the right to counsel. Butler lield that a waiver can be inferred "from the actions and words of the person interrogated." 118 Although the case only involved the invocation of the right to silence, there was no indication that its holding was limited to that circumstance. In fact, in noting that ten of the eleven circuits have already rejected the need for an explicit waiver, the Butler Court cited a number of right to counsel cases. ${ }^{119}$ Recently, a number of circuit courts have specifically relied on Butler to find an implied waiver of the right to counsel after that right had been invoked. ${ }^{120}$ In light of $E d w a r d s$, these decisions are highly questionable, since in none of them did the defendant "imitiate" the reinterrogation. ${ }^{121}$ All waivers of the right to counsel are dependent on the "necessary fact that the accused, not the police, reopened the dialogue with the authorities." 122

J., concurring), is thus an overstatement. Interrogation may take place after the suspect's attorney has arrived, subject of course, to the requirement that a waiver of the right to silence be voluntary, knowing and imtelligent.

116. See Michigan v. Mosley, 423 U.S. at 102.

117. 441 U.S. 369 (1979).

118. Id at 373 .

119. Id. at 375 n.5. e.g., United States v. Marchildon, 519 F.2d 337 (8th Cir. 1975); United States v. Cooper, 499 F.2d 1060 (D.C. Cir. 1974); United States v. Cavallino, 498 F.2d 1200 (5th Cir. 1974); United States v. Hayes, 385 F.2d 375 (4th Cir. 1967).

120. E.g. Kennedy v. Fairman, 618 F.2d 1242, 1246-47 (7th Cir. 1980); United States v. Nick, 604 F.2d 1199, 1201 (9th Cir. 1979).

121. See text acconupanying notes 108-09 supra.

122. Edwards v. Arizona, $101 \mathrm{~S}$. Ct. at 1885 n.9.

The history of People v. Braeseke, 25 Cal. 3d 691, 602 P.2d 384, 159 Cal. Rptr. 684 (1980), cert. denied, $101 \mathrm{~S}$. Ct. 3015 (1981), offers a clue as to the potential impact of Edwards on Butler. After being arrested for nuurdering a number of his relatives, and being advised of his Miranda rights, Braeseke invoked his right to counsel. Subsequently he asked the officer to speak with him alone and "off the record." The request was granted. Eventually Braeseke gave a fall description of the niurders. In a 4-3 decision, the California Supreme Court reversed the conviction on the gronnds that because he had not been wamed that anything he said "off the record" could be used against him, Braeseke had not knowingly and intelligently waived his right to counsel. People v. 
In light of the empirical studies discussed earlier, ${ }^{123}$ the difficult question is whether $E d w a r d s$ will have any effect on criminal procedure im practice. If the giving of warnings remains an ineffective deterrent to talking, and should most suspects contmue to waive their right to counsel in any event, then the import of Edwards inay be more illusory than real. But to the extent that police officers frustrate Miranda's goals by causing suspects to waive their right to counsel once they liave already invoked it, and induce them to speak when they would not otherwise do so, ${ }^{124}$ Edwards' potential effect is far from insignificant. That its command inay only apply to those suspects who lave once invoked their right to counsel does nothing to lessen its overall importance. The vindication of constitutional rights is no less noteworthy because its effects are felt by a limited group of individuals.

Even if the $E d w a r d s$ decision has no practical effect, in that the number of waivers, the number of confessions and the number of convictions largely remain the saine, it does not necessarily follow that $E d$ wards has had no impact. A decision like $E d w a r d s$ serves an important educational function. For suspects, it contributes to a greater awareness of their rights. One study mdicates that such an awareness may be of more value to the suspect taken into custody than the actual recitation of warnings. ${ }^{125}$ Moreover, Edwards ensures that these rights will not be waived by virtue of custodial coercion. If suspects choose to waive their rights they will have done so on their own accord or after being educated by an attorney. For the police, the Edwards decision serves to better define the limits of their power. This will help to ensure "the recognition of fundainental rights and the constitutional performance of professional duties." 126 And for the public, a more general cognizance that the Court intends to give meaningful safeguards to

Braeseke, 25 Cal. 3d at 702-03, 602 P.2d at 390-91, 159 Cal. Rptr. at 690-91. The United States Supreme Court vacated the judgment and remanded the case for consideration of whether it was based on federal or state grounds. California v. Braeseke, 446 U.S. 932 (1980). In his memorandum approving the application for a stay of execution, Justice Rehnquist stated that "if it was decided on the basis of federal constitutional law, it comes extraordinarily close to the adoption of a rule that in no cases can waiver be inferred from the actions and words of the person interrogated." 444 U.S. 1309, 1310 (1980) (mem.). Upon reconsideration, the California court certified that its judgment was based on federal grounds, and affirmed its decision. 28 Cal. 3d 86, 618 P.2d 149, 168 Cal. Rptr. 603 (1980). The state appealed once again, and jnst one week after Edwards was decided, the Supreme Court denied certiorari. $101 \mathrm{~s}$. Ct. 3015 (1981). In light of its earlier remand-with the obvious implication that if decided on federal grounds, the loolding was of doubtful validity-this derial may indicate that a majority of the Court endorses the view that Butler's implied waiver does not apply in right to counsel cases.

123. See notes $89-98$ and accompanying text supra.

124. See notes 68-69 and accompanying text supra.

125. Interrogations in New Haven, supra note 83, at 1615.

126. Stepliens, Flanders \& Cannon, supra note 92, at 431. See generally White, supra note 67; Waiver of Rights in Police Interrogations, supra note 48. 
Miranda's guarantees will bolster confidence and trust in the law enforcement system.

\section{CONCLUSION}

The Court's decision in Edwards represents a noticeable departure from the consistency of post-Miranda opinions. That it was handed down without dissent is particularly surprising in light of the Burger Court's record of chipping away at Miranda. Even more significant is that the Court went beyond merely overturning the Arizona Supreme Court, and erected a per se rule to further protect the right to counsel during custodial interrogation. Thus, despite the fears of Burger Court critics, Edwards should dispel any notion that Miranda is soon to be overruled. More iniportantly, Edwards may symbolize a renewed recognition of the underlying concern of the Miranda Court, to establish meaningful and effective safeguards of the suspect's fifth amendment rights. The right to have counsel present during interrogation is one such crucial safeguard. It was identified in Miranda; it was affirnatively protected in $E d w a r d s$. Many beheve that this will reduce the number of confessions. As a practical matter, this is uncertaim. As a jurisprudential matter, the words of Justice Frankfurter are appropriate: "Law triumphs when the natural impulses aroused by a shocking crime yield to the safeguards which our civilization has evolved for an administration of criminal justice at once rational and effeetive."127 The decision in Edwards is an encouraging step in that direction.

Wayne L. Bender*

127. Watts v. Indiana, 338 U.S. 49, 55 (1949).

* B.A. 1979, Yale University; third-year student, Boalt Hall School of Law, University of California, Berkeley. 